\title{
Beyond lobbying: the political determinants of adopting corporate social responsibility frameworks in the European Union and the USA
}

\author{
Patrick Bernhagen ${ }^{1}$ D $\cdot$ Kelly Kollman ${ }^{2} \cdot$ Natalka Patsiurko $^{3}$
}

Accepted: 28 January 2022 / Published online: 2 March 2022

(c) The Author(s) 2022

\begin{abstract}
This paper explores the role of corporate social responsibility (CSR) as an element in a corporation's political action repertoire. Previous research has studied lobbying and CSR as a distinct means by which corporations seek to manage their nonmarket environment. Analyzing CSR as a political activity, we argue that corporations engage in CSR for the same reasons that prompt them to engage in lobbying. More specifically, we expect corporations to adopt CSR frameworks that are suitable to enhance their reputation in a given political arena. To evaluate this argument, we analyze the lobbying and CSR behavior in the EU and USA of over 2000 corporations from around the world. Our results show that lobbying and adopting CSR frameworks can be predicted by similar empirical models. Moreover, controlling for common predictors and endogeneity, lobbying in the EU is associated with an increased likelihood of a corporation adopting an appropriate CSR framework. However, corporations that lobby in Washington DC become less likely to engage in CSR the more they spend on lobbying. These findings shed new light on the relationship between lobbying and CSR while highlighting important differences in corporate non-market behavior across political arenas.
\end{abstract}

Keywords Corporate political activity - Corporate social responsibility · Lobbying · Corporate citizenship $\cdot$ Non-market activity $\cdot$ CSR washing

Patrick Bernhagen

patrick.bernhagen@sowi.uni-stuttgart.de

1 Department of Political Science and Political Sociology, University of Stuttgart, Breitscheidstraße 2, 70174 Stuttgart, Germany

2 School of Social and Political Sciences, University of Glasgow, Glasgow, UK

3 Department of Sociology \& Anthropology, Concordia University, Montreal, Canada 


\section{Introduction}

Corporations make up an important part of the lobbying community in many political systems (see, e.g., Aizenberg and Hanegraaff 2020 for an overview). In addition to lobbying, increasing numbers of corporations participate in corporate social responsibility (CSR) schemes, including various forms of private or self-regulation, by which a corporation or a group of corporations subjects itself to stricter environmental, human rights, labor or social standards than what is required by law (Mellahi et al. 2016). At first glance, CSR and lobbying seem to have little in common. Lobbying is aimed at securing private benefits for a corporation, such as public procurement or subsidies (Hillman and Riley 1989; Tullock 1967) or collective benefits for an industry, such as favorable regulation, price guarantees or tax reductions (Grier et al. 1994; Olson 1965). By contrast, CSR involves the provision of public goods by private actors (see, e.g., Baron 2001; Prakash and Potoski 2006). While lobbying frequently takes place outside the view of the public, CSR is usually intended to be publicly visible (Mutch and Aitken 2009) — to the extent that corporations have to be careful to avoid accusations of "CSR-washing" (Pope and Wæraas 2016).

Standard accounts of CSR emphasize benefits to society (e.g., Williams 2014) or market benefits to the corporation (see Mellahi et al. 2016 for an overview). Some authors emphasize a shift in norms for acceptable business behavior (e.g., Dashwood 2012), suggesting that business goals have expanded to include social, environmental and human rights aspirations in addition to profits. Research on corporate involvement in the United Nations Global Compact (UNGC) suggests that corporations sign up in order to build trust, manage risk, network with other corporations, and explore new business opportunities (Rasche 2020). We argue in this paper that corporations adopt CSR frameworks for political reasons. CSR can enhance corporations' access to, and build stronger relations with, key policymakers. If this argument is correct, we should observe that the same corporate characteristics and conditions in a corporation's political environment that account for its lobbying also drive its adoption of CSR frameworks. Moreover, we argue that corporations use CSR to support their lobbying. If this second argument is correct, we should observe that a corporation's lobbying activities contribute to predicting its decisions to adopt CSR frameworks. Specifically, we argue that corporations that lobby in a given arena are more likely than other corporations to adopt CSR frameworks that are highly regarded in that arena.

Investigating this argument and its empirical implications is normatively important, as corporations have been suspected of using CSR initiatives strategically to avert legal accountability and weaken regulation (Vogel 2007). As Bénabou and Tirole (2010, p. 10) note, "CSR could be a means of placating regulators and public opinion to avoid strict supervision in the future". This means that any progress in sustainability, human rights, or social and labor standards accruing from CSRrelated activities may be reversed by the setbacks that result from anti-regulatory lobbying facilitated by the very same CSR activities. Similar concerns have been voiced with regard to corporate philanthropy (Bertrand et al. 2020). However, to 
date we have little empirical insight into the extent to which corporations employ CSR for the same political reasons that motivate their lobbying.

To shed light on the relationship between lobbying and CSR, we begin by summarizing the main insights in the literature in a standard model of corporate political activity. We argue that this model also serves to account for much of the variance in CSR. In a second step, we develop a theoretical argument for the expectation that CSR is a complementary non-market measure employed to support lobbying. We argue that corporations take arena-specific norms and conventions into account when selecting an appropriate CSR instrument to support their lobbying. To investigate the implied patterns and relationships empirically, we analyze the political and CSR participation of large corporations in the policymaking centers of the world's largest markets - the USA and the European Union (EU). Our empirical analysis makes use of a dataset containing information on the lobbying and CSR behavior of over 2000 corporations from 43 countries around the world. Our cross-national data enable us to investigate the arena-specificity of CSR while controlling for the role played by the home country context. The results show, firstly, that lobbying and CSR can be predicted by similar empirical models. Secondly, controlling for common predictors and endogeneity, lobbying in the EU is associated with an increased likelihood of a corporation pursuing arena-specific CSR-related activities. However, looking only at corporations that lobby in Washington DC, spending more on lobbying does not increase the likelihood to adopt a CSR framework. These findings shed new light on the relationship between lobbying and CSR while highlighting important differences in corporate non-market behavior across political arenas.

\section{Explaining corporations' non-market behavior in different arenas}

Corporations engage in non-market activities in a variety of ways, usually with the aim of influencing policymakers or societal actors, such as labor unions and other non-governmental organizations (NGOs). As political actors, corporations are aware that their reputation and the trust of key actors in the political arena and in civil society are intangible yet crucial assets. Managing these assets is a key part of a corporation's non-market strategy. CSR can help achieve this in two principal ways: First, the legitimacy that a corporation can gain by participating in CSR initiatives can reduce the threat of adverse activity by NGOs or policymakers (Lim and Tsutsui 2012). Second, when adverse political developments loom, e.g., in the form of costly legislation or product boycotts, countervailing political measures can be employed more effectively if a corporation enjoys a good reputation and legitimacy (den Hond et al. 2014). CSR helps corporations to develop relevant political networks, to offset the reputational fallout from political activity, and to distinguish themselves from their competitors in the political arena.

While lobbying and CSR have been studied separately for decades, it is only recently that scholars have begun to examine the link between the two. Still, most studies addressing this relationship are theoretical. Den Hond et al. (2014) have conceptualized the different ways in which corporations (fail to) align their CSR 
and lobbying activities. According to these scholars, a corporation may lobby and use CSR to try to attain the same or similar policy goals, or it may fail to coordinate these activities. It can also focus its CSR and lobbying on similar issues but aim at different outcomes, e.g., committing to reduce its greenhouse gas emissions while lobbying against stricter regulation of such emissions" (den Hond et al. 2014). Rasche (2015) distinguishes a North American approach to corporate non-market activity focusing mainly on lobbying from a European approach emphasizing "political CSR". ${ }^{1}$ He suggests that some of the differences between these approaches can be explained by reference to the political environment. Echoing concerns voiced by Vogel (2007), Rasche also posits that both lobbying and political CSR share a common interest in the deterrence of stronger government regulation. In the literature on corporate political behavior, such an interest is generally assumed: Corporate political activities are seen either as responses to threatening developments such as adverse regulatory activity or as proactive attempts to obtain more preferable political decisions (cf. Getz 1997). The role played by CSR in this context is less clear. Drawing on the resource-based view of corporate political behavior, Rehbein and Schuler (2015) propose that the mechanism linking CSR with lobbying is the effect of CSR on the development of corporate resources, as CSR serves to enhance a corporation's human capital, organizational capital, and geographic resources, which in turn improve the effectiveness of lobbying.

Empirical investigations of the relationship between CSR and lobbying are rare. The few that exist are mostly restricted to a single country (Hadani and Coombes 2015; Werner 2015) or rely on experimental data (Malhotra et al. 2019). For the USA, Hadani and Coombes (2015) find that one particular variant of CSR-corporate philanthropy-is predicted by the same industry-level stimuli as corporate lobbying. Werner (2015) has shown that CSR can help corporations gain access to policymakers in Washington DC. And Malhotra et al. (2019) report experimental evidence supporting the expectation that corporations use private regulations as a political strategy to preempt more stringent public regulations. In a rare crossnational empirical investigation, Favotto and Kollman (2021) have analyzed if and how corporations coordinate the work of their CSR and public affairs units to improve the quality of their lobbying disclosure reports. While pursuing different research questions, all of these analyses assume that politically active corporations adopt CSR frameworks that increase their organization's legitimacy and improve their reputation among relevant policymakers. Yet to date this assumption has not been confronted directly with empirical data. Thus, of Vogel's call "to explore the relationship between business adoption of voluntary standards and their efforts to influence public policies" (2008, p. 267), the most fundamental question has not been addressed yet: is there empirical evidence for such a relationship in the first place? We contribute to filling this gap by analyzing the relationship between corporate lobbying and CSR within a single theoretical framework and in the context

\footnotetext{
1 The concept of "political CSR" has been coined by Scherer and Palazzo $(2011,901)$ to describe "an extended model of governance with business corporations contributing to global regulation and providing public goods".
}

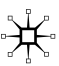


of cross-national data. In other words, we take a step back to investigate whether the empirical relationship that motivates studies of coordination and alignment between the two types of non-market activity can actually be observed for a large, cross-national sample of corporations. We go beyond correlation by asking whether CSR and lobbying are responses to the same set of stimuli in a corporation's political environment. To this end, firstly, we formulate and test a set of generic hypotheses derived from the standard model of corporate political activity. Secondly, we develop and test original hypotheses about the role of CSR within a corporation's political action repertoire.

\section{Common correlates of lobbying and CSR}

The standard model of corporate political activity posits that corporations enter the political arena with the aim of obtaining political decisions that increase their future returns (see, e.g., Grier et al. 1994; Hansen et al. 2005; Stigler 1971). We argue that this model accounts not only for narrowly defined political activities such as lobbying, but also for less traditional political activities like CSR. This implies that the factors that have been identified in the literature to account for variation in lobbying should also explain variation in CSR strategies. Following the main insights of the relevant literature (Grier et al. 1994; Hillman et al. 2004; Lux et al. 2011), we expect a number of factors at the corporate, industry and country levels to structure corporations' incentives for participating in these non-market activities.

At the level of the corporation, the literature has identified corporate size, ownership structure and the tax load as determinants of corporate lobbying. First, a corporation's size reflects its resources and market power as well as what it has at stake in economic and political conflict (Grier et al. 1994). As larger corporations have more to gain from political activity than smaller ones, at least in absolute terms, they will frequently ignore the free-rider incentives of others (Olson 1965). Many larger corporations also have increased reputational incentives for participating in non-market activity, as they have to protect publicly visible brand names. In previous empirical research, corporate size has consistently been an important determinant not only of political activity (Hansen and Mitchell 2000) but also of CSR-related activities and voluntary disclosure (Bennie et al. 2007).

Second, the decisions that corporations make about participating in non-market activities might be affected by their ownership type. Rehbein et al. (2013) suggest that corporate non-market strategies are affected by shareholder activism, to which privately held corporations or family-owned businesses are not subject. Concerning CSR, Dasgupta et al. (2000) posit that publicly traded corporations whose good environmental performance is publicized receive premia in the market. We expect similar premia to accrue in the political arena. Third, the extent to which a corporation is subject to taxation affects its decisions to engage in politics. However, while taxation is one of the most important channels through which governments affect the net profitability of a corporation, the literature to date has produced mixed findings. One the one hand, Richter et al. (2009) found that corporations that lobby subsequently pay lower income taxes. On the other 
hand, Drope and Hansen (2008) found that corporations that spend more in an effort to affect policy generally or tax policy specifically are no more likely to benefit from lower tax rates than others. While this result casts doubt on the effectiveness of lobbying, it also points to the possibility that corporations with a larger tax burden perceive - and act upon-a greater need to lobby for reductions. Since the EU does not have a direct role in raising taxes, this logic does not apply here. By contrast, the corporate lobbying community in Washington DC contains many corporations liable to federal corporate income tax. Thus, for the two arenas under consideration, the standard model of corporate political activity that has been established in the literature implies the following three associations between corporate characteristics and non-market behavior:

H1a: The likelihood to lobby and/or adopt a CSR framework increases with a corporation's size.

H1b: Publicly traded corporations are more likely than privately held or family-owned corporations to lobby and/or adopt a CSR framework.

H1c: The likelihood to lobby and/or adopt a CSR framework in the USA increases with a corporation's tax bill.

At the industry level, corporate participation in both politics and social responsibility is shaped by the type of their main area of activity. Firstly, corporations in extractive industries are exposed to increased decision making by public authorities, as their activities are usually subject to stricter licensing requirements than most other industries (Evans 1988). With natural resources such as oil, gas and minerals often located in politically difficult environments, corporations in these industries also face criticism by environmental and human rights groups. Corporations active in these areas lobby policymakers and seek opportunities to enhance their reputation and public legitimacy. Secondly, the aerospace and defense industry is highly exposed to government decision making, as governments are the main customers and tightly control exports. Thirdly, based on Olson's (1965) classic argument, the literature posits an effect of market concentration on corporations' non-market strategy. While analyses of concentration within an industry have generated mixed findings (Grier et al. 1994; Hansen and Mitchell 2000; Hansen et al. 2005), the dominant view in the literature holds that models of corporate non-market activity should take market concentration into account (Hansen et al. 2005). Thus, we expect that.

H1d: Corporations in the extractive industries are more likely to lobby and/ or adopt a CSR framework.

H1e: Corporations in the aerospace and defense industry are more likely to lobby and/or adopt a CSR framework.

H1f: The likelihood to lobby and/or adopt a CSR framework increases with the degree of market concentration in the corporation's main industry.

At the country level, there is evidence that even multinationals' non-market behavior is shaped by their national origin (Bucheli and Salvaj 2014). Comparative studies of CSR have shown that globally active corporations reflect the political context of their 
home countries even when engaging in non-market activity beyond that context (Berliner and Prakash 2012; Bernhagen et al. 2013; Perkins and Neumayer 2010). Firstly, home country characteristics affect the extent to which NGOs can challenge and influence the actions of corporations. Such opportunities are higher in liberal democracies, which also enable corporations to pursue a wider array of (legal) non-market strategies than autocratic systems. Thus, the degree of democracy in a corporation's home country should be a predictor of both its lobbying and its CSR strategies. Secondly, the home country's system of interest intermediation has been argued, and found, to affect corporate non-market strategies elsewhere. Pluralist systems like the USA, UK, and Australia, are characterized by numerous and competing interest groups, all struggling for access to policymakers. By contrast, corporatist systems have more centralized and hierarchically ordered interest associations with privileged access to the policymaking process as well as institutionalized bargaining between business, labor and the government (Streeck and Kenworthy 2005). Examples include Austria, the Netherlands and the Scandinavian countries. While this has been expected to encourage less direct corporate lobbying (Greenwood 2002), more recent research has found that corporations from corporatist systems match (Bernhagen and Mitchell 2009) and even surpass (Marshall and Bernhagen 2017) the lobbying activity of their peers from pluralist systems. Thus, we specify a positive effect of corporatism on non-market activity. Applying these country-level arguments to our research question about the determinants of lobbying and CSR leads us to expect that:

H1g: The likelihood to lobby and/or adopt a CSR framework increases with the level of democracy in the corporation's home country.

H1h: The likelihood to lobbying and/or adopt a CSR framework increases with the level of corporatism in the corporation's home country.

\section{The effects of lobbying on CSR}

While our review of the standard model of corporate political activity leads us to expect that the same set of factors drives both lobbying and CSR, it does not tell us whether corporations that lobby are also more likely to adopt a CSR framework. To address this question, we combine insights from the literature and interviews with CSR managers to develop our argument that corporations employ CSR to facilitate their role as a political actor. Our point of departure is the assumption that legitimacy is a key asset underpinning any corporate political strategy. We argue that displaying a credible commitment to CSR contributes to the production and maintenance of this asset in two principal ways.

First, adopting a CSR framework helps corporations improve their relationships with NGOs and policymakers. Perceptions of social responsibility and community engagement enhance corporations' images among NGOs and policymakers alike, facilitating interactions between corporations and these external actors. As a CSR manager from the UK put it, "sustainability activities create a dialogue with NGOs". ${ }^{2}$ Global and highly visible initiatives such as the UNGC serve to

\footnotetext{
${ }^{2}$ Interview UK CSR Manager 27/1/2015.
} 
institutionalize such dialogue and create a communicative environment between actors whose relationship is often conflictual. As a "relational activity" (den Hond et al. 2014, p. 793), CSR thus leads to contacts that may subsequently be deployed by the corporation in its political strategies. This logic underlies Werner's study (2015), who argues that policymakers use corporations' sociopolitical reputation as a heuristic device when deciding whom to grant access. According to this argument, a good sociopolitical reputation sets a corporation apart from its competitors and increases the likelihood that a policymaker will grant that corporation access. If a policymaker needs to associate with lobbyists, doing so with reputable actors reduces the potential of future associative risk for the policymaker. Corporations with strong CSR reputations may also have novel information derived from these activities that policymakers can use to inform their legislative decisions and when drafting policy. Indeed, government actors increasingly encourage the adoption of CSR frameworks, especially in Europe. As one manager from a British financial corporation put it, "[regulators] have a massively disproportionate influence [on sustainability practices]. We've got no choice, have we?". 3 Therefore, as Werner (2015) argues, policymakers grant access preferentially to organizations that have established reputations for behaving in a socially responsible manner. Assuming that corporations recognize this link, those that seek access to lobby policymakers should be more likely than others to engage in reputation-enhancing behavior. However, to date this implication has not been investigated.

Second, CSR offsets the reputational costs of lobbying. As den Hond et al. (2014, p. 796) summarize, lobbying "can tarnish the reputation of a firm". Campaign contributions from political action committees (PACs) are often portrayed in the media as a legal form of corruption (Milyo et al. 2000) and in many countries lobbying has a poor image (Rozbicka et al. 2021). Corporate managers are rightly concerned about how the public views them and how this affects their interactions with policymakers. In the words of one CSR manager we interviewed, "politicians will reflect public sentiment. That is their job". ${ }^{4}$ Thus, corporations that lobby have additional incentives to adopt a CSR framework compared with corporations for whom lobbying is less central.

Like other actors and organizations, corporations have incentives to behave according to what is considered appropriate (March and Olsen 1989). These incentives are particularly strong when a corporation enters the political arena-an arena in which the public feels business corporations do not belong. If CSR can enhance a corporation's political reputation and engender legitimacy in the eyes of external actors as well as offset the reputational costs of lobbying, corporations can be expected to choose activities that are well-regarded in the relevant political arena and wider social context. Anecdotal evidence from elite interviews also suggests that corporations seek to participate in CSR schemes that have reputational capital in the respective political arenas in which they are active. As one British manager

\footnotetext{
3 Interview UK CSR Manager 4/9/2015.

4 Interview UK CSR Manager 22/9/2015.
}

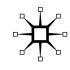


put it when explaining why their company participates in certain codes, "it helps if you can say UN ... just because it is a global recognizable brand". 5 A US CSR manager, by contrast, noted that US companies tend not participate in the UNGC in part because their stakeholders "don't ask [if they are members]". ${ }^{6}$ In the eyes of CSR managers, what is considered reputation-enhancing varies across political arenas. This implies that, when choosing a specific format of CSR, corporations consider the value attributed to it in the relevant normative and institutional environment. Based on these considerations we expect that,

$\mathrm{H} 2 \mathrm{a}$ : Corporations that lobby in Washington DC are more likely than other corporations to adopt a CSR framework that is highly regarded in the USA.

$\mathrm{H} 2 \mathrm{~b}$ : Corporations that lobby in Brussels are more likely than other corporations to adopt a CSR framework that is highly regarded in the EU.

\section{Data and measurement}

To test these hypotheses, we have compiled a quota sample of corporations from around the world. While previous studies have focused on corporations from a single country (mainly the USA) or at most a small number of countries, our sample ensures good representation of different regions of the world. To investigate the implied patterns and relationships empirically, we analyze the political and CSR participation of large corporations in the policymaking centers of the world's largest markets- the USA and the European Union (EU).Our comparative view on the EU and US political systems also enables us to contribute to research investigating the differences and similarities between these two lobby arenas (Mahoney 2008; Mahoney and Baumgartner 2008; Woll 2012). The differences between these two systems include their dominant modes of interest representation (Beyers et al. 2016), adding to the external validity of our findings. Corporations' demographic and financial data are taken from Standard and Poor's Capital IQ database, which at the time of drawing the sample (March 2013) contained almost 60000 public and more than $1.7 \mathrm{~m}$ private companies from all over the world. From this population frame, we sampled the 302 largest corporations, from Germany, the 303 largest from the UK and, initially, the 300 largest US corporations, as well as the largest 1113 corporations from the rest of the world. The quotas for German, British and US corporations ensure good representation of the major types of political-economic system (corporatist vs. pluralist, and majoritarian vs. consensus). To this end, we have created a size ranking based on corporate revenues, profits, assets and employee numbers. ${ }^{7}$ A sample of the largest corporations in any modern capitalist system is dominated by publicly traded entities. Due to the size of the US economy, there are relatively few private companies among the top 300 in that country. To

\footnotetext{
5 Interview UK CSR Manager 4/9/2015.

6 Interview US CSR Manager 1/5/2015.

7 Following established practice in the literature, size is measured by revenues (in units of million US Dollars). Profit is gross profit revenues in million US Dollars realized. Assets are total current assets of the corporation in million US Dollars, while the number of employees is the total number of employees of a corporation. All size measures refer to the financial year 2012.
} 
ensure sufficient variation on ownership type among US corporations, we oversampled private corporations in the USA by adding the next largest 53 private corporations from the population database to this subsample. The final sample contains 2071 corporations from 43 countries representing all regions of the world.

Corporations adopt voluntary frameworks to signal their CSR to external actors such as citizens, policymakers and NGOs (Cao and Prakash 2011). To measure CSR adoption, we follow established practice (Berliner and Prakash 2012, Lim and Tsutsui 2012, van den Broek 2021) and use two widely endorsed global CSR frameworks. Our argument about the relationship between lobbying and CSR implies that CSR strategies take the political context in account. To test our expectation that corporations that lobby in a given arena are more likely than other corporations to adopt a CSR framework that is highly regarded in that arena, we require CSR frameworks that carry reputational capital in the respective political arenas. For the USA, CSR adoption is measured by the Sustainability Reporting Framework provided by the Global Reporting Initiative (GRI). Established in Boston in 1997, the GRI is an NGO that has developed and disseminates sustainability reporting guidelines for the disclosure of corporate economic, environmental, and social activities. In 2013, more than 5000 organizations were registered with the GRI, and the vast majority of these (3872) filed CSR reports based on the GRI framework. The scheme promotes the measurement and disclosure of a corporation's environmental and social impacts, setting improvement targets and reporting progress toward these goals. These practices and procedures are promoted by prominent, multistakeholder initiatives such as ISO 26000 that seek to improve corporations' sustainability performance and have become markers of corporations' engagement with this community and the issues they promote (Loconto and Fouilleux 2014). The GRI guidelines also correspond neatly with the accounting practices familiar to US-listed corporations and policymakers in Washington DC. GRI is a dichotomous measure of CSR participation, coded 1 if the corporation was signed up to the GRI in 2013 (0 otherwise).

Our indicator of appropriate CSR in the EU context is the UNGC. Involvement in this public-private voluntary initiative enables corporations to build up their social and environmental reputation with a format that is particularly valuable in the context of the EU: The European Commission actively encourages corporations to put in place "a process to integrate social, environmental, ethical, human rights and consumer concerns into their business operations and core strategy" (European Commission 2011, p. 6). In particular, the Commission explicitly invites large corporations to make a commitment to take account of at least one of three public-private voluntary initiatives when developing their approach to CSR, including the UNGC. ${ }^{8}$ Thus, corporations seeking to lobby the EU institutions have considerable incentives to adopt this CSR framework. UNGC is a dichotomous variable, coded 1 if the corporation was signed up to the UNGC in 2013 (0

\footnotetext{
${ }^{8}$ The other two are the OECD Guidelines for Multinational Enterprises and the ISO 26000 Guidance Standard on Social Responsibility. Notably, the Commission's guidance does not include the GRI.
} 
otherwise). ${ }^{9}$ Of the 2071 corporations in our sample, 761 (36.8 percent) participate in the GRI and 493 (23.8 percent) are signatories to the UNCG. 321 corporations (15.5 percent) are involved in both schemes, whose bivariate correlation is phi $=0.32$. Among US corporations, the share of GRI participants (also 36.8 percent) is slightly higher than among corporations headquartered in the EU (31.6 percent). Conversely, at 24.1 percent, the share of UNGC signatories is considerably higher among EU corporations than among US corporations (10.5 percent). This comparison supports the view that the GRI is valued particularly in the USA, whereas the UNGC has a greater potential of commanding respect in the EU.

Our measures of corporate lobbying focus on the policymaking centers of the world's largest markets-Washington DC and Brussels. In these arenas, policymakers legislate on the terms under which goods and services can be produced and traded in the US and EU markets, respectively. Not surprisingly, Washington DC and Brussels have attracted lobbying from corporations headquartered outside as well as inside their borders for several decades. Lobbying data for the USA is taken from the Center for Responsive Politics on the basis of Congressional lobby reporting data. We have coded a corporation as lobbying in Washington DC (DC lobbying $=1$ ) if it has filed a lobby expenditure report for the year 2013 as required under the 1995 Lobbying Disclosure Act. For parts of the analysis we also use expenditure figures in US Dollars as supplied under the Act and made available by the Centre for Responsive Politics.

Lobbying data for the EU has been collected through corporation-level searches of the 2013 European Public Affairs Directory (Harris 2013). A corporation is coded as engaging in EU-level lobbying if it has a public affairs office in Brussels (Brussels lobbying $=1$ ). This measure indicates a substantial level of political commitment in the form of sunk costs (Coen and Vannoni 2020). Setting up a European public affairs post is useful for targeting all three major policymaking bodies of the EU-the Commission, the Council of Ministers, and the European Parliament. Equipping this representative with his/her own office in Brussels is costlier still, and a Brussels base is useful for corporations seeking to play a role in European public affairs. Thus, the measure records whether a corporation is willing to invest in in-house lobbying infrastructure at the level of the EU. While these are coarse measures (many corporations lobby in other arenas and in ways that are not reflected in office infrastructure or expenditure reports), they are the only comparable measures for a large number of corporations from around the globe. Quantitative and comparable information at the corporation level on the amount or intensity of lobbying is available for the USA only. Table 1 shows percentages of corporations

\footnotetext{
${ }^{9}$ Since then, both the GRI and UNGC have undergone several changes. In 2018, the UNGC diversified its mode of engagement. Until then, corporations committed to the ten Principles of the UNGC through a letter of commitment and by reporting progress on how these principles were implemented (the "signatory" status). A newly created "participant" status involves more networking activities and access to more resources, as well as demanding a higher fee. Since this latter option was not available to corporations at the time of our data collection and to avoid confusion, we refer to adoption, involvement or signing up, rather than participation in the UNGC. While the GRI has been developed almost continuously in recent years, these changes largely concern the definition and measurement of the different levels of reporting rather than the more general utility of the reporting tool for corporations.
} 
Table 1 Percentages of corporations participating in non-market activities per country of headquarter, top 25 countries in sample, listed in descending order of adopting a CSR framework (GRI and/or $U N G C$ )

\begin{tabular}{|c|c|c|c|c|c|}
\hline Country of HQ & $\mathrm{N}$ in sample & GRI & UNGC & DC Lobbying & $\begin{array}{l}\text { Brussels Lob- } \\
\text { bying }\end{array}$ \\
\hline Denmark & 11 & 63.6 & 100.0 & 9.1 & 9.1 \\
\hline Norway & 9 & 77.8 & 88.9 & 11.1 & 33.3 \\
\hline Finland & 10 & 90.0 & 80.0 & 10.0 & 20.0 \\
\hline South Korea & 47 & 63.8 & 68.1 & 6.4 & 0.0 \\
\hline Sweden & 30 & 70.0 & 50.0 & 16.7 & 20.0 \\
\hline Spain & 27 & 74.1 & 14.8 & 14.8 & 7.4 \\
\hline Taiwan & 32 & 75.0 & 0.0 & 0.0 & 0.0 \\
\hline Netherlands & 37 & 64.9 & 35.1 & 21.6 & 10.8 \\
\hline South Africa & 29 & 55.2 & 37.9 & 3.5 & 0.0 \\
\hline Brazil & 32 & 59.4 & 59.4 & 0.0 & 0.0 \\
\hline India & 30 & 63.3 & 23.3 & 10.0 & 0.0 \\
\hline Australia & 34 & 55.9 & 35.3 & 5.9 & 2.9 \\
\hline Switzerland & 46 & 56.5 & 43.5 & 26.1 & 10.9 \\
\hline Chile & 8 & 62.5 & 12.5 & 0.0 & 0.0 \\
\hline Russia & 31 & 54.8 & 6.5 & 0.0 & 0.0 \\
\hline Mexico & 20 & 60.0 & 30.0 & 10.0 & 5.0 \\
\hline Belgium & 12 & 58.3 & 25.0 & 25.0 & 25.0 \\
\hline Italy & 30 & 50.0 & 33.3 & 13.3 & 36.7 \\
\hline Ireland & 17 & 47.1 & 11.8 & 35.3 & 0.0 \\
\hline Japan & 223 & 29.2 & 38.1 & 13.0 & 9.4 \\
\hline France & 78 & 32.1 & 26.9 & 19.2 & 19.2 \\
\hline Turkey & 10 & 50.0 & 20.0 & 0.0 & 0.0 \\
\hline Canada & 66 & 40.9 & 16.7 & 33.3 & 0.0 \\
\hline Singapore & 18 & 33.3 & 22.2 & 16.7 & 0.0 \\
\hline USA & 353 & 36.8 & 10.5 & 69.1 & 11.3 \\
\hline \multicolumn{6}{|l|}{$\cdots$} \\
\hline All countries & 2071 & 36.8 & 23.8 & 21.2 & 8.1 \\
\hline
\end{tabular}

participating in non-market activities per country of headquarter for the top 25 countries in the sample, listed in descending order of adopting a CSR framework (GRI and/or $U N G C$ ).

Size is measured by revenues realized during the financial year $2012 .^{10}$ The tax bill of the corporation is measured by Income Tax, defined as government tax on the profits earned during the financial year (2012) in billion US Dollars. Private corporations are those privately held and family-owned corporations that are not indexed in any stock market.

\footnotetext{
${ }^{10}$ In the analysis below, these are expressed in units of 10 billion US Dollars to avoid excessive decimal places when reporting probit coefficients.
} 


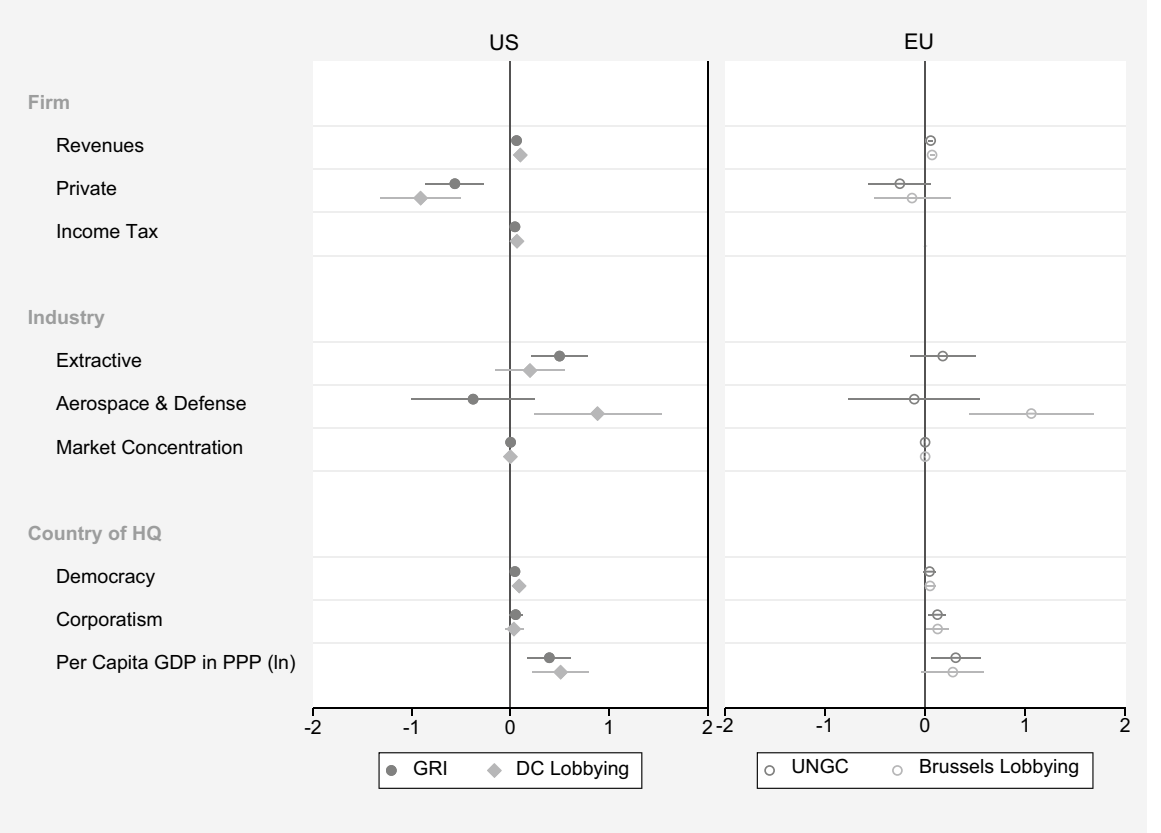

Fig. 1 Probit coefficients for predictors of lobbying and adopting a CSR framework in the USA and EU. The figure shows probit coefficient estimates with 95 percent confidence intervals $(N=1953$ (1865 for Brussels lobbying))

To identify industrial sectors, we follow Grier et al. (1994) and use the industry group as indicated by the first three digits of the Standard Industrial Classification (SIC). We measure market concentration using the Herfindahl-Hirschman Index, calculated for each industry group and adjusted for the different group sizes within our sample through multiplying by group size and normalizing the result to range between 0 and 1. Industry groups with fewer than three corporations are excluded from the analysis. The two particularly exposed industries, extractive industries and aerospace and defense, are included as dummy variables in the multivariate analysis.

Democracy is measured using Polity IV data (Marshall et al. 2016). We expect the representation of societal demands within a political system to vary continuously with the degree of democracy: In partial or illiberal democracies or in competitively authoritarian systems, there will likely be more, and more diverse, lobbying than in the most oppressive systems. Therefore, we use the full 21-point Polity IV scale of democracy. To measure corporatism, we use the coordination of wage setting in 2013. Taken from Visser (2015), this is an ordinal scale of five categories ranging from "fragmented wage bargaining, confined largely to individual corporations or plants" (=1) to "maximum or minimum wage rates/increases based on centralized bargaining" (=5).

In the analysis below, we control for the level of the home country's economic development. This is measured as per capita GDP at purchasing power parity 
$(P P P)$, taken from the World Bank. Finally, to control for the fact that for some corporations, Washington DC and Brussels are also arenas for local lobbying, we include dummy variables indicating whether the corporations' headquarters are in the USA, the EU, or in Belgium. Summary statistics of all variables are provided in Table 2 in the Appendix.

\section{Results}

To gauge the extent to which the standard model of corporate political activity can predict lobbying and CSR (Hypotheses 1a-h), we estimate generalized linear models with a probit link function. We specify random intercepts at the country level to allow for effects of unobserved influences of a corporation's national origins. The probit coefficient estimates (with 95 percent confidence intervals) for the predictors of lobbying and CSR behavior at the corporate, industry and country levels are shown in Fig. 1. Full numerical estimates are reported in the Appendix (Table 3).

The estimated coefficient for corporate size (Revenues) is statistically significant across all modes and arenas of non-market activity, supporting Hypothesis 1a. Private ownership (Hypothesis $1 \mathrm{~b}$ ) is negatively associated with lobbying in Washington DC and with GRI participation. By contrast, ownership type has no effect on lobbying in Brussels or on signing up to the UNGC. Finally, the amount of income tax paid (Hypothesis 1c) is positively associated with lobbying in DC and with GRI participation.

Turning to the level of the industry, corporations in the extractive sector (Hypothesis 1d) are significantly more likely than other corporations to report on their CSR participation using the GRI framework. However, the coefficient for this industry is not statistically significant in any other model. ${ }^{11}$ Corporations in the aerospace and defense industry are significantly more likely to lobby in Washington DC and Brussels (Hypothesis 1e), but the likelihood of CSR adoption is not significantly different from those in other industries. There is no effect of market concentration on any of the non-market activities (Hypothesis 1f).

At the level of the corporation's home country, the likelihood to lobby in DC and to use the GRI increases significantly with the level of democracy in the corporation's home country (Hypothesis $1 \mathrm{~g}$ ). While a corporation's propensity to lobby in Brussels or to join the UNGC is also related to the degree of democracy in their home country, the coefficient estimate for neither of these two activities is statistically significant. Finally, the degree of corporatism in the country in which a corporation is headquartered (Hypothesis $1 \mathrm{~h}$ ) is positively related to Brussels lobbying and UNGC involvement. However, there is no association between corporatism and lobbying in Washington DC or participating in the GRI.

Turning to the control variables, there is a positive relationship between the level of the home country's economic development and the various non-market activities.

\footnotetext{
11 Extractive was dropped from the model for Brussels lobbying as it predicts this dependent variable perfectly.
} 
However, in the case of Brussels lobbying, the coefficient estimate is not statistically significant. The corporate headquarter dummies for the EU and the USA have significant coefficients of the expected sign. However, Belgian headquarters are unrelated to lobbying in Brussels.

Overall, the estimates reported in Fig. 1 reveal more similarities than differences between the determinants of lobbying and CSR, supporting the expectation that the standard model of corporate political activity also serves to predict CSR. In particular, the pattern that emerges suggests bigger differences between the "American" arenas of non-market activity (lobbying in Washington DC and participating in the GRI) on the one hand and the "European" ones (lobbying in Brussels and signing up to the UNGC) on the other, than between lobbying and CSR.

To move beyond patterns of coefficients and significance, we conduct a formal test of proportionality, i.e., of the hypothesis that the coefficients of the lobbying and CSR models are equal within each policy arena (Washington DC and Brussels). The null hypothesis states that the relative effects of the substantive predictorsrevenues, ownership type, income tax (in Washington DC), market concentration, democracy, and corporatism-do not differ between the dependent variables lobbying and adopting a CSR framework. To exemplify formally for the US arena, the hypothesis of proportionality of the coefficients between the GRI model and the DC Lobbying model is:

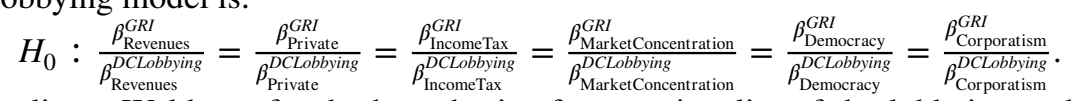

nonlinear Wald test for the hypothesis of proportionality of the lobbying and CSR models yields low and insignificant Chi-square values for the US models $\left(\chi^{2} 3.94\right.$, $p=0.56)$ and for the EU models $\left(\chi^{2}=0.92, p=0.92\right) .{ }^{12}$ Thus, for both arenas, we fail to reject the null hypothesis that the coefficients of the lobbying and CSR equations are proportional. This lends further support to the expectation that corporations' lobbying and CSR choices can be explained by the same standard model of corporate political activity. They differ only in the extent to which corporations in specific industries lobby and adopt a CSR framework, respectively.

Hypothesis 2 states that (a) lobbying in Washington DC is associated with an increased likelihood of engaging in CSR initiatives that are well-regarded in the USA and that (b) lobbying in Brussels is associated with an increased likelihood of engaging in CSR initiatives that are well-regarded in the EU. To test these expectations, lobbying measures are included in empirical models of CSR. Since our measures of lobbying and CSR are not only predicted by the same set of variables but both related to one another, the lobbying measure might be endogenous to CSR,

\footnotetext{
12 The combined estimation results from the lobbying and CSR models were obtained using the seemingly unrelated estimation (SUEST) command in Stata (Mize et al. 2019. A General Framework for Comparing Predictions and Marginal Effects across Models. Sociological Methodology, 49, 152-89. Since we know from the probit coefficients that the industry dummies (Extractive, Aerospace and Defense) have noticeably different effects on lobbying and CSR, we exclude these variables as well as the constant and the control variables from the proportionality tests.
} 
Fig. 2 Marginal effects of lobbying on the likelihood to adopting the GRI (from instrumental variable probit) and UNGC (from multilevel probit) frameworks
0.50

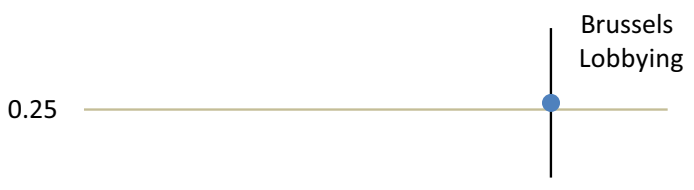

0.00

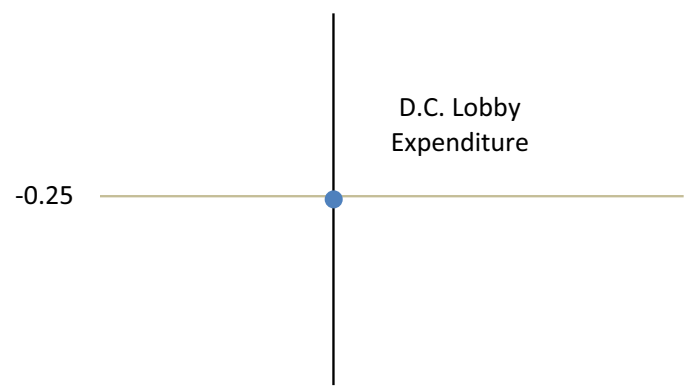

$-0.50$

which would render single equation estimates inconsistent. A Wald test of exogeneity yields a high significant chi-square $(\chi=8.95, p=0.003)$ for the US arena, indicating that DC Lobbying is endogenous and should not be used as a predictor of GRI in single equation probit regression. Instrumental variable (IV) probit regression requires endogenous covariates to be continuous, a criterion that is not met by the lobbying measures used in the analysis so far. Fortunately, a continuous measure of lobbying is available for the USA in the form of lobby expenditure figures in US Dollars supplied under the under the 1995 Lobbying Disclosure Act. ${ }^{13}$ This enables us to test for the 439 corporations in our sample that do lobby in Washington DC whether spending more on lobbying increases the likelihood of engaging in a CSR. Two variables, US headquarters and aerospace and defense, are correlated with DC lobby expenditure but not with GRI participation and therefore will be used to instrument the endogenous regressor. By contrast, the endogeneity test for Brussels

\footnotetext{
${ }^{13}$ Expenditure figures enter the analysis in units of 1 million USD; the natural log is taken to ameliorate the skew of the distribution.
} 
lobbying yields $\chi=0.08$ with $p=0.30$, so that the null hypothesis of no endogeneity cannot be rejected. This makes a single equation probit regression preferable for the EU arena. Thus, the effect of DC lobby expenditure on GRI participation is estimated using instrumental variable probit with a conditional maximum-likelihood estimator and error correction allowing for intragroup correlation within home countries. ${ }^{14}$ The effect of Brussels lobbying on $U N G C$ involvement is estimated for a single equation multilevel probit model similar to the one producing the coefficients reported in Fig. 1, but with Brussels lobbying included as a predictor variable. The full results are reported in Table 4 in the Appendix.

Figure 2 shows the marginal effects of lobbying on CSR. Holding all other regressors constant at their means, the marginal effect of DC Lobbying Expenditure on GRI participation, is -0.25 with a 95 -percent confidence interval (CI) of [ -0.44 , $-0.07]$. Since the expenditure variable is $\log$ transformed for better model fit, we interpret the effect of a relative increase: $-0.253 * \ln (2)=-0.076$ means that if a corporation were to double its lobbying expenditure in Washington DC, its expected likelihood of participating in the GRI decreases by a little under 8 percent. This result runs counter to the expectation expressed in Hypothesis 2a. Rather than making CSR more attractive to corporations, spending more on lobbying in Washington DC has a negative effect on CSR participation. ${ }^{15}$ However, since we do not strictly test Hypothesis 2a, this hypothesis can neither be falsified nor supported at this point.

By contrast, Brussels Lobbying is a positive predictor of $U N G C$ involvement The marginal effect of Brussels Lobbying on UNGC involvement is 0.26 with a 95-percent CI of $[0.18,0.33]$. Thus, the expected likelihood of a corporation participating in the UNGC is between 18 and 33 percent higher for Brussels lobbyists than for corporations who do not lobby there, ceteris paribus. This result supports the expectation expressed in Hypothesis $2 \mathrm{~b}$ that an appropriate form of CSR is employed by corporations as a complement to their lobbying in Brussels. Interestingly, the findings reported in Fig. 2 and Table 4 are broadly similar when UNGC involvement is predicted by DC lobby expenditure and also when GRI participation is predicted by Brussels lobbying (see Table 5 in the Appendix). Thus, while similar models of corporate political activity predict GRI participation and DC lobbying, and UNGC involvement and Brussels lobbying, respectively, the association between lobbying and CSR is largely independent of the chosen CSR scheme. Rather, whether there is a positive or a negative relationship between lobbying and CSR depends on the political arena, although the nature of that relation differs in our analysis, referring to discrete choice in the case of the EU while describing the effect of a continuous spending variable for corporations that had already decided to lobby in Washington DC

\footnotetext{
14 Alternatively, Newey's two-step estimator was employed. This precluded cluster correction of the standard errors but confirms the findings reported below.

15 The negative effect of lobby expenditure on the likelihood of adopting CSR framework also obtains if we include all 2071 corporations in our sample, assuming that corporations that did not file a lobby expenditure report spent exactly zero USD on lobbying in Washington DC during 2013.
} 


\section{Discussion}

The literatures on corporate political activity and social responsibility increasingly point to the possibility that corporations use CSR as a means to support their more overtly political activities, such as lobbying (Malhotra et al. 2019; Hadani and Coombes 2015; Werner 2015). Our analysis contributes to these literatures by empirically assessing two hitherto untested implications of these studies: that joining CSR programs is motivated by the same factors as lobbying, and that lobbying adds further to the likelihood of a corporation adopting an appropriate CSR framework. To do so, we have identified and applied a standard model of corporate political activity, according to which corporations enter the political arena with the aim of obtaining political decisions that increase their profits (see, e.g., Grier et al. 1994; Hansen et al. 2005; Stigler 1971). We have argued that this model accounts not only for narrowly defined political activities such as lobbying, but also for less traditional political activities like CSR.

Our findings show that CSR framework adoption and lobbying can indeed be predicted by very similar empirical models. Considering that corporations adapt their non-market strategies to the arena of their lobbying, we have found that most of the factors that predict lobbying also predict CSR. As much of the literature has argued (Drope and Hansen 2006; Hadani and Coombes 2015; Mellahi et al. 2016), corporate size continues to be the best predictor of corporate political participation. Our findings also show that corporate size is a robust predictor of CSR adoption: The larger a corporation, the more likely it is to lobby in Washington DC, to lobby in Brussels, to use the reporting framework of the GRI or sign up to the UNGC. Furthermore, publicly traded corporations are more likely to lobby in Washington DC and join the GRI than privately held corporations. By contrast, ownership type does not seem to affect corporate non-market strategies in the EU. Washington DC lobbying and GRI participation also become more likely the higher a corporation's individual tax bill. Thus, there are clear arena-specific patterns of corporations' nonmarket behavior. Because the observed patterns are found in a sample of corporations from around the world, our cross-country analysis highlights the fact that these differences are arena effects. However, as has been suggested in other works comparing these two political arenas (Mahoney 2008; Mahoney and Baumgartner 2008; Woll 2012), the observed differences do not mean that lobbyists adhere to fundamentally different logics. Rather, in the EU and the USA alike, corporations respond to political stimuli by lobbying, and they seek to support their lobbying with the appropriate CSR framework. What differs between these political systems are the frameworks that are considered most appropriate.

At the industry level, differences between CSR and lobbying are more pronounced, while differences between political arenas are less important. In particular, the usual suspects of aerospace and defense corporations lobby over-proportionately in both Brussels and DC, but without matching these activities with the expected appropriate CSR. This is in line with earlier work by Bennie et al. (2007), who found no positive effect of aerospace and defense on the likelihood of signing up to the UNGC. One reason for this might be that the lobbying of corporations 
in aerospace and defense is more about subsidies, procurement and export permits than about regulation. Decisions on subsidies and contracts are distributive in the sense identified by Lowi (1964, p. 690): They are "highly individualized decisions ... in which the loser and the recipient, need never come into direct confrontation." In the context of such policies, there is arguably less need for sociopolitical reputation to support a corporation's lobbying efforts.

At the country level, we find that corporations' propensities to lobby in Washington DC and register with the GRI increase with the level of democracy in their country of headquarters. This suggests that the incentives of corporations from democratic countries to develop lobbying capabilities and adopt CSR programs travel to the political arena of the USA but not the EU. By contrast, the likelihood to lobby in Brussels and to participate in the UNGC increases with the degree of corporatism in the home country, but this has no bearing on lobbying in Washington DC or registering with the GRI. This supports previous research pointing to the increasing need and capacity of corporations from corporatist systems to lobby in Brussels (Bernhagen and Mitchell 2009; Marshall and Bernhagen 2017).

Jointly, these findings suggest that the explanations that have been advanced in the literature to account for corporate lobbying also serve to account for adoption of CSR frameworks. Moreover, the findings highlight the similarity of lobbying and CSR relative to the differences between the political arenas of the EU and the USA. While corporations' non-market strategies are shaped by their material interests and profit-seeking behavior, the appropriate strategies to pursue these interests vary across political arenas with their specific institutional incentives and prevailing norms.

Our results also shed light on the expectation that corporations use CSR as an accompanying measure to support their lobbying strategy. The findings from this part of the analysis have to be interpreted with caution, as different lobby measures and different models have been used. Bearing this caveat in mind, the analysis has further highlighted arena-specific differences: In the EU, the likelihood of a corporation engaging in CSR increases considerably if this corporation lobbies in the political arena. By contrast, increasing lobbying expenditure in Washington DC decreases the likelihood of participating in CSR. Thus, while in the EU CSR seems to serve as a complement of lobbying, in the USA the relationship seems to be one of substitution: The more a corporation invests in lobbying, the less likely it is to take part in CSR schemes. This result likely reflects the fact that the EU has actively promoted the uptake of some CSR frameworks and encouraged corporations to improve their non-financial corporate disclosure since the late 1990s (Kinderman 2020). However, against the backdrop of recent findings that CSR can help corporations gain access to policymakers in Washington DC (Werner 2015), the fact that corporations' lobbying could not be shown to increase their likelihood of adopting a CSR framework is puzzling. One explanation for this might be that corporations that lobby in DC under-estimate the political value of CSR in this arena, perhaps because the US government has not promoted the uptake of such frameworks as clearly or consistently as the European Commission despite the value policymakers place on them. Alternatively, while CSR is taken up by a corporation partly because it engages in lobbying in the first place, thus serving as a complement to lobbying, our findings may also suggest that more intensive lobbying makes CSR redundant. 
Our conclusion is necessarily preliminary. More research is needed to examine the internal decision processes corporations undertake to combine their CSR and lobbying activities and the implications this has for effective environmental, human rights, labor and social standards. In addition, the above analysis has raised a new puzzle: While the decision to lobby has been shown to prompt the adoption of CSR frameworks, among those corporations that lobby, spending more money on it reduces the likelihood of adopting a CSR framework.

\section{Appendix}

$2,3,4,5$.

Table 2 Summary statistics of all variables

\begin{tabular}{llllll}
\hline Variable & Obs & Mean & SD & Min & Max \\
\hline DC Lobbying & 2071 & 0.21 & 0.41 & 0 & 1 \\
DC Lobby expenditure (1 m \$) & 439 & 2.33 & 3.16 & .01 & 20.59 \\
Brussels Lobbying & 2071 & 0.08 & 0.27 & 0 & 1 \\
GRI & 2071 & 0.37 & 0.48 & 0 & 1 \\
UNGC & 2071 & 0.24 & 0.43 & 0 & 1 \\
Revenues (10bn \$) & 2071 & 1.78 & 3.33 & 0.00 & 46.92 \\
Private & 2071 & 0.07 & 0.25 & 0 & 1 \\
Income tax & 2060 & 0.47 & 1.71 & -34.83 & 31.05 \\
Extractive & 2071 & 0.04 & 0.20 & 0 & 1 \\
Aerospace and defense & 2071 & 0.01 & 0.11 & 0 & 1 \\
Market concentration & 1960 & 77.90 & 15.91 & 0 & 100 \\
Democracy & 2071 & 8.22 & 4.72 & -8 & 10 \\
Corporatism & 2071 & 2.39 & 1.55 & 0 & 5 \\
Per Capita GDP (PPP in 1,000 \$) & 2071 & 3.63 & 0.44 & 1.66 & 4.17 \\
USA & 2071 & 0.17 & 0.38 & 0 & 1 \\
EU & 2071 & 0.42 & 0.49 & 0 & 1 \\
Belgium & 2071 & 0.01 & 0.08 & 0 & 1 \\
\hline & & & & \\
\hline
\end{tabular}


Table 3 Multilevel probit regression for lobbying and adopting a CSR framework

\begin{tabular}{|c|c|c|c|c|}
\hline & DC Lobbying & GRI & Brussels Lobbying & UNGC \\
\hline Revenues & $\begin{array}{l}0.101 * \\
(0.014)\end{array}$ & $\begin{array}{l}0.062 * \\
(0.012)\end{array}$ & $\begin{array}{c}0.071 * \\
(0.009)\end{array}$ & $\begin{array}{c}0.059^{*} \\
(0.010)\end{array}$ \\
\hline Private & $\begin{array}{l}-0.910 * \\
(0.209)\end{array}$ & $\begin{array}{l}-0.564 * \\
(0.151)\end{array}$ & $\begin{array}{l}-0.138 \\
(0.195)\end{array}$ & $\begin{array}{l}-0.241 \\
(0.157)\end{array}$ \\
\hline Income Tax & $\begin{array}{l}0.067 * \\
(0.024)\end{array}$ & $\begin{array}{l}0.046^{*} \\
(0.021)\end{array}$ & & \\
\hline Extractive Industries & $\begin{array}{l}0.199 \\
(0.181)\end{array}$ & $\begin{array}{l}0.498 * \\
(0.147)\end{array}$ & & $\begin{array}{l}0.186 \\
(0.166)\end{array}$ \\
\hline Aerospace and defense & $\begin{array}{l}0.884 * \\
(0.329)\end{array}$ & $\begin{array}{l}-0.378 \\
(0.320)\end{array}$ & $\begin{array}{l}1.062 * \\
(0.318)\end{array}$ & $\begin{array}{l}-0.111 \\
(0.336)\end{array}$ \\
\hline Market concentration & $\begin{array}{l}0.000 \\
(0.003)\end{array}$ & $\begin{array}{l}0.002 \\
(0.002)\end{array}$ & $\begin{array}{l}-0.000 \\
(0.003)\end{array}$ & $\begin{array}{l}-0.000 \\
(0.002)\end{array}$ \\
\hline Democracy & $\begin{array}{l}0.089 * \\
(0.031)\end{array}$ & $\begin{array}{l}0.046^{*} \\
(0.020)\end{array}$ & $\begin{array}{l}0.049 \\
(0.028)\end{array}$ & $\begin{array}{l}0.046 \\
(0.032)\end{array}$ \\
\hline Corporatism & $\begin{array}{l}0.036 \\
(0.047)\end{array}$ & $\begin{array}{l}0.053 \\
(0.036)\end{array}$ & $\begin{array}{l}0.125^{*} \\
(0.056)\end{array}$ & $\begin{array}{l}0.123^{*} \\
(0.044)\end{array}$ \\
\hline Per Capita GDP (PPP in $1000 \$$ ) & $\begin{array}{l}0.510 * \\
(0.146)\end{array}$ & $\begin{array}{c}0.395^{*} \\
(0.113)\end{array}$ & $\begin{array}{l}0.276 \\
(0.159)\end{array}$ & $\begin{array}{l}0.303^{*} \\
(0.127)\end{array}$ \\
\hline USA & $\begin{array}{l}1.814^{*} \\
(0.539)\end{array}$ & $\begin{array}{l}-0.543 \\
(0.498)\end{array}$ & $\begin{array}{l}0.669 \\
(0.470)\end{array}$ & $\begin{array}{l}-0.696 \\
(0.886)\end{array}$ \\
\hline EU & $\begin{array}{l}0.368 \\
(0.247)\end{array}$ & $\begin{array}{l}-0.065 \\
(0.205)\end{array}$ & $\begin{array}{l}0.668 * \\
(0.249)\end{array}$ & $\begin{array}{l}0.291 \\
(0.339)\end{array}$ \\
\hline Belgium & & & $\begin{array}{l}0.361 \\
(0.590)\end{array}$ & \\
\hline Constant & $\begin{array}{l}-4.444 * \\
(0.707)\end{array}$ & $\begin{array}{l}-2.163 * \\
(0.506)\end{array}$ & $\begin{array}{l}-3.823 * \\
(0.725)\end{array}$ & $\begin{array}{l}-2.484 * \\
(0.598)\end{array}$ \\
\hline Variance Component: Country & $\begin{array}{l}0.246 \\
(0.134)\end{array}$ & $\begin{array}{l}0.220^{*} \\
(0.081)\end{array}$ & $\begin{array}{l}0.157 \\
(0.096)\end{array}$ & $\begin{array}{l}0.716^{*} \\
(0.252)\end{array}$ \\
\hline Wald $\chi^{2}$ & $132.02 *$ & $96.03 *$ & $90.56^{*}$ & $58.52 *$ \\
\hline $\mathrm{N}$ & 1949 & 1949 & 1872 & 1959 \\
\hline
\end{tabular}

Cell entries are probit coefficients, with standard errors in parentheses. $* p<0.05$ 
Table 4 Multilevel probit regression of adopting a CSR framework on lobbying

\begin{tabular}{|c|c|c|}
\hline & GRI (IV Probit) & $\begin{array}{l}\text { UNGC (Multi- } \\
\text { level Probit) }\end{array}$ \\
\hline DC Lobby Expenditure & $\begin{array}{l}-0.253^{*} \\
(0.093)\end{array}$ & \\
\hline Brussels Lobbying & & $\begin{array}{l}0.934 * \\
(0.115)\end{array}$ \\
\hline Revenues & $\begin{array}{l}0.063 * \\
(0.015)\end{array}$ & $\begin{array}{l}0.044 * \\
(0.010)\end{array}$ \\
\hline Income Tax & $\begin{array}{l}0.006 \\
(0.008)\end{array}$ & \\
\hline Extractive Industries & $\begin{array}{l}0.285 \\
(0.298)\end{array}$ & $\begin{array}{l}0.272 \\
(0.163)\end{array}$ \\
\hline Aerospace and defense & & $\begin{array}{l}-0.369 \\
(0.327)\end{array}$ \\
\hline Democracy & $\begin{array}{l}0.045 \\
(0.019)\end{array}$ & $\begin{array}{l}0.039 \\
(0.033)\end{array}$ \\
\hline Corporatism & & $\begin{array}{l}0.114 * \\
(0.043)\end{array}$ \\
\hline Per Capita GDP (PPP in $1000 \$$ ) & & $\begin{array}{l}0.288^{*} \\
(0.125)\end{array}$ \\
\hline EU & & $\begin{array}{l}0.269 \\
(0.344)\end{array}$ \\
\hline Constant & $\begin{array}{l}-0.630^{*} \\
(0.189)\end{array}$ & $\begin{array}{l}-2.462^{*} \\
(0.567)\end{array}$ \\
\hline
\end{tabular}

First-stage estimates

\begin{tabular}{|c|c|c|}
\hline \multirow[t]{2}{*}{ Revenues } & \multicolumn{2}{|l|}{$0.079 *$} \\
\hline & \multicolumn{2}{|l|}{$(0.009)$} \\
\hline \multirow[t]{2}{*}{ Income Tax } & \multicolumn{2}{|l|}{$0.019 *$} \\
\hline & \multicolumn{2}{|l|}{$(0.008)$} \\
\hline \multirow[t]{2}{*}{ Extractive } & \multicolumn{2}{|l|}{-0.232} \\
\hline & \multicolumn{2}{|l|}{$(0.263)$} \\
\hline \multirow[t]{2}{*}{ Democracy } & \multicolumn{2}{|l|}{0.011} \\
\hline & \multicolumn{2}{|l|}{$(0.064)$} \\
\hline \multirow[t]{2}{*}{ Aerospace and defense } & \multicolumn{2}{|l|}{$1.259 *$} \\
\hline & \multicolumn{2}{|l|}{$(0.361)$} \\
\hline \multirow[t]{2}{*}{ USA } & \multicolumn{2}{|l|}{$1.240 *$} \\
\hline & \multicolumn{2}{|l|}{$(0.155)$} \\
\hline \multirow[t]{2}{*}{ Constant } & \multicolumn{2}{|l|}{-0.970} \\
\hline & \multicolumn{2}{|l|}{$(0.607)$} \\
\hline \multirow[t]{2}{*}{ Variance Component: Country } & & $0.770 *$ \\
\hline & & $(0.265)$ \\
\hline Wald $\chi^{2}$ & $33.94 *$ & 126.30 * \\
\hline $\mathrm{N}$ & 427 & 2071 \\
\hline
\end{tabular}

Cell entries are probit coefficients, with standard errors in parentheses (corrected for clustering on country in the instrumental variable model). ${ }^{*} p<0.05$ 
Table 5 Multilevel probit regression of adopting a CSR framework on lobbying (alternative lobby-CSR match)

\begin{tabular}{|c|c|c|}
\hline & UNGC (IV Probit) & $\begin{array}{l}\text { GRI } \\
\text { (Multilevel } \\
\text { Probit) }\end{array}$ \\
\hline DC Lobby Expenditure & $\begin{array}{l}-0.511^{*} \\
(0.058)\end{array}$ & \\
\hline Brussels Lobbying & & $\begin{array}{l}0.572 * \\
(0.113)\end{array}$ \\
\hline Revenues & $\begin{array}{l}0.055^{*} \\
(0.012)\end{array}$ & $\begin{array}{l}0.061^{*} \\
(0.011)\end{array}$ \\
\hline Private & $\begin{array}{l}-0.233 \\
(0.189)\end{array}$ & $\begin{array}{l}-0.525^{*} \\
(0.142)\end{array}$ \\
\hline Income Tax & $\begin{array}{l}0.023 \\
(0.013)\end{array}$ & \\
\hline Extractive & $\begin{array}{l}-0.300 \\
(0.194)\end{array}$ & $\begin{array}{l}0.561^{*} \\
(0.144)\end{array}$ \\
\hline Aerospace and defense & & $\begin{array}{l}-0.427 \\
(0.298)\end{array}$ \\
\hline Democracy & $\begin{array}{l}0.024 \\
(0.023)\end{array}$ & $\begin{array}{l}0.044 * \\
(0.020)\end{array}$ \\
\hline Corporatism & & $\begin{array}{l}0.058 \\
(0.036)\end{array}$ \\
\hline Per Capita GDP (PPP in 1000 \$) & & $\begin{array}{l}0.392 * \\
(0.110)\end{array}$ \\
\hline EU & & $\begin{array}{l}-0.078 \\
(0.212)\end{array}$ \\
\hline Constant & $\begin{array}{l}-0.939 * \\
(0.206)\end{array}$ & $\begin{array}{l}-2.064 * \\
(0.470)\end{array}$ \\
\hline
\end{tabular}

First-stage estimates

$\begin{array}{lc}\text { Revenues } & 0.080^{*} \\ & (0.010) \\ \text { Private } & -0.468 \\ & (0.361) \\ \text { Income Tax } & 0.019^{*} \\ & (0.008) \\ \text { Extractive } & -0.241 \\ & (0.268) \\ \text { Democracy } & -0.011 \\ & (0.064) \\ \text { Aerospace and defense } & 0.932^{*} \\ & (0.383) \\ \text { USA } & 1.241 * \\ & (0.150) \\ \text { Constant } & -0.968 \\ & (0.609)\end{array}$

Variance Component: Country 
Table 5 (continued)

\begin{tabular}{lll}
\hline & UNGC (IV Probit) & $\begin{array}{l}\text { GRI } \\
\text { (Multilevel } \\
\text { Probit) }\end{array}$ \\
\hline Wald $\chi^{2}$ & & $(0.089)$ \\
$\mathrm{N}$ & $158.89 *$ & $122.52 *$ \\
& 438 & 2071 \\
\hline
\end{tabular}

Cell entries are probit coefficients, with standard errors in parentheses (corrected for clustering on country in the instrumental variable model). $* p<0.05$

Funding The research for this paper was supported by the Economic and Social Research Council (grant ID ES/I036974/1). Open Access funding enabled and organized by Projekt DEAL.

\section{Declarations}

Conflict of interest On behalf of all authors, the corresponding author states that there is no conflict of interest.

Open Access This article is licensed under a Creative Commons Attribution 4.0 International License, which permits use, sharing, adaptation, distribution and reproduction in any medium or format, as long as you give appropriate credit to the original author(s) and the source, provide a link to the Creative Commons licence, and indicate if changes were made. The images or other third party material in this article are included in the article's Creative Commons licence, unless indicated otherwise in a credit line to the material. If material is not included in the article's Creative Commons licence and your intended use is not permitted by statutory regulation or exceeds the permitted use, you will need to obtain permission directly from the copyright holder. To view a copy of this licence, visit http://creativecommons.org/licenses/by/4.0/.

\section{References}

Aizenberg, E., and M. Hanegraaff. 2020. Is politics under increasing corporate sway? A longitudinal study on the drivers of corporate access. West European Politics 43: 181-202.

Baron, D.P. 2001. Private politics, corporate social responsibility, and integrated strategy. Journal of Economics and Management Strategy 10: 7-45.

Bénabou, R., and J. Tirole. 2010. Individual and Corporate Social Responsibility. Economica 77: 1-19.

Bennie, L., P. Bernhagen, and N.J. Mitchell. 2007. The logic of transnational action: The good corporation and the global compact. Political Studies 55: 733-753.

Berliner, D., and A. Prakash. 2012. From norms to programs: The United Nations global compact and global governance. Regulation and Governance 6: 149-166.

Bernhagen, P., and N.J. Mitchell. 2009. The determinants of direct corporate lobbying in the European Union. European Union Politics 10: 155-176.

Bernhagen, P., N.J. Mitchell, and M. Thissen-Smits. 2013. Corporate citizens and the UN global compact: Explaining cross-national variations in turnout. Business and Politics 15: 63-85.

Bertrand, M., M. Bombardini, R. Fisman, and F. Trebbi. 2020. Tax-exempt lobbying: Corporate philanthropy as a tool for political influence. American Economic Review 110: 2065-2102.

Beyers, J., D. De Bièvre, M. Hanegraaff, \& A. Poletti. 2016. International institutions and interest mobilization: the WTO and lobbying in EU and US trade policy. Journal of World Trade, 289-312.

Bucheli, M., and E. Salvaj. 2014. Adaptation Strategies of Multinational Corporations, State-Owned Enterprises, and Domestic Business Groups to Economic and Political Transitions: A Network Analysis of the Chilean Telecommunications Sector, 1958-2005. Enterprise and Society 15: 534-576. 
Cao, X., and A. Prakash. 2011. Growing exports by signaling product quality: Trade competition and the crossnational diffusion of ISO 9000 quality standards. Journal of Policy Analysis and Management 30: 111-135.

Coen, D., and M. Vannoni. 2020. The Strategic Management of Government Affairs in Brussels. Business and Society 59: 612-641.

Commission, E. 2011. COMMUNICATION FROM THE COMMISSION TO THE EUROPEAN PARLIAMENT, THE COUNCIL, THE EUROPEAN ECONOMIC AND SOCIAL COMMITTEE AND THE COMMITTEE OF THE REGIONS: A renewed EU strategy 2011-14 for Corporate Social Responsibility, $\operatorname{COM}(2011) 681$ final. Brussels.

Dasgupta, S., H. Hettige, and D. Wheeler. 2000. What Improves Environmental Compliance? Evidence from Mexican Industry. Journal of Environmental Economics and Management 39: 39-66.

Dashwood, H.S. 2012. The Rise of Global Corporate Social Responsibility: Mining and the Spread of Global Norms. Cambridge: Cambridge University Press.

Den Hond, F., K.A. Rehbein, F.G.A. De Bakker, and H. Kooijmans-Van Lankveld. 2014. Playing on Two Chessboards: Reputation Effects between Corporate Social Responsibility (CSR) and Corporate Political Activity (CPA). Journal of Management Studies 51: 790-813.

Drope, J.M., and W.L. Hansen. 2006. Does Firm Size Matter? Analyzing Business Lobbying in the United States. Business and Politics 8: 1-17.

Drope, J.M., and W.L. Hansen. 2008. Futility and free-riding: Corporate political participation and taxation rates in the United States. Business and Politics 10: 1-23.

Evans, D. 1988. Oil PACs and Aggressive Contribution Strategies. The Journal of Politics 50: $1047-1056$.

Favotto, A., and K. Kollman. 2021. Mixing business with politics: Does corporate social responsibility end where lobbying transparency begins? Regulation and Governance 15: 262-279.

Getz, K.A. 1997. Research in Corporate Political Action: Integration and Assessment. Business and Society 36: 32-72.

Greenwood, J. 2002. The effectiveness of EU business associations, Basingstoke, Palgrave.

Grier, K., M. Munger, and B. Roberts. 1994. The determinants of industry political activity, 19781986. American Political Science Review 88: 911.

Hadani, M., and S. Coombes. 2015. Complementary Relationships Between Corporate Philanthropy and Corporate Political Activity: An Exploratory Study of Political Marketplace Contingencies. Business and Society 54: 859-881.

Hansen, W.L., and N.J. Mitchell. 2000. Disaggregating and explaining corporate political activity: Domestic and foreign corporations in national politics. American Political Science Review 94: 891.

Hansen, W.L., N.J. Mitchell, and J.M. Drope. 2005. The Logic of Private and Collective Action. American Journal of Political Science 49: 150-167.

Hillman, A.L., and J.G. Riley. 1989. Politically contestable rents and transfers. Economics and Politics 1: 17-39.

Hillman, A.J., G.D. Keim, and D. Schuler. 2004. Corporate Political Activity: A Review and Research Agenda. Journal of Management 30: 837-857.

Kinderman, D. 2020. The challenges of upward regulatory harmonization: The case of sustainability reporting in the European Union. Regulation and Governance 14: 674-697.

Lim, A., and K. Tsutsui. 2012. Globalization and Commitment in Corporate Social Responsibility: Cross-National Analyses of Institutional and Political-Economy Effects. American Sociological Review 77: 69-98.

Loconto, A., and E. Fouilleux. 2014. Politics of private regulation: ISEAL and the shaping of transnational sustainability governance. Regulation and Governance 8: 166-185.

Lowi, T.J. 1964. American Business, Public Policy, Case-Studies, and Political Theory. World Politics 16: $677-715$.

Lux, S., T.R. Crook, and D.J. Woehr. 2011. Mixing business with politics: A meta-analysis of the antecedents and outcomes of corporate political activity. Journal of Management 37: 223-247.

Mahoney, C. 2008. Brussels versus the beltway: Advocacy in the United States and the European Union. Georgetown University Press.

Mahoney, C., and F. Baumgartner. 2008. Converging Perspectives on Interest Group Research in Europe and America. West European Politics 31: 1253-1273.

Malhotra, N., B. Monin, and M. Tomz. 2019. Does Private Regulation Preempt Public Regulation? American Political Science Review 113: 19-37.

March, J. G. \& Olsen, J. P. 1989. Rediscovering institutions : the organizational basis of politics, New York, Free Pr. [u.a.]. 
Marshall, D., and P. Bernhagen. 2017. Government-business relations in multilevel systems: The effect of conflict perception on venue choice. West European Politics 40: 981-1003.

Marshall, M. G., Gurr, T. R. \& Jaggers, K. 2016. Polity iv project: Political regime characteristics and transitions, 1800-2015. Dataset Users' Manual. On-line (http://www.systemicpeace. org/polity/ polity4. htm). Center for Systemic Peace.

Mellahi, K., J.G. Frynas, P. Sun, and D. Siegel. 2016. A Review of the Nonmarket Strategy Literature: Toward a Multi-Theoretical Integration. Journal of Management 42: 143-173.

Milyo, J., D. Primo, and T. Groseclose. 2000. Corporate PAC contributions in perspective. Business \& Politics 2: 75.

Mize, T.D., L. Doan, and J.S. Long. 2019. A General Framework for Comparing Predictions and Marginal Effects across Models. Sociological Methodology 49: 152-189.

Mutch, N., and R. Aitken. 2009. Being fair and being seen to be fair: Corporate reputation and CSR partnerships. Australasian Marketing Journal (AMJ) 17: 92-98.

Olson, M. 1965. The Logic of Collective Action: Public Goods and the Theory of Groups. Cambridge: Harvard University Press.

Perkins, R., and E. Neumayer. 2010. Geographic Variations in the Early Diffusion of Corporate Voluntary Standards: Comparing ISO14001 and the Global Compact. Environment and Planning C: Government Policy 42: 347-365.

Pope, S., and A. Wæraas. 2016. CSR-Washing is Rare: A Conceptual Framework, Literature Review, and Critique. Journal of Business Ethics 137: 173-193.

Prakash, A., and M. Potoski. 2006. The Voluntary Environmentalists: Green Clubs, ISO 14001, and Voluntary Environmental Regulations. Cambridge: Cambridge University Press.

Rasche, A. 2015. The corporation as a political actor-European and North American perspectives. European Management Journal 33: 4-8.

Rasche, A. 2020. Research Handbook of Responsible Management. The United Nations Global Compact and the Sustainable Development Goals. Edward Elgar Publishing.

Rehbein, K., and D.A. Schuler. 2015. Linking Corporate Community Programs and Political Strategies. Business and Society 54: 794-821.

Rehbein, K., J.M. Logsdon, and H.J. Van Buren. 2013. Corporate Responses to Shareholder Activists: Considering the Dialogue Alternative. Journal of Business Ethics 112: 137-154.

Richter, B.K., K. Samphantharak, and J.F. Timmons. 2009. Lobbying and Taxes. American Journal of Political Science 53: 893-909.

Rozbicka, P., Kamiński, P., Novak, M. \& Jankauskaite, V. 2021. Conclusions: The Future of Lobbying in the CEE Countries. Achieving Democracy Through Interest Representation: Interest Groups in Central and Eastern Europe. Cham: Springer International Publishing.

Stigler, G.J. 1971. The Theory of Economic Regulation. The Bell Journal of Economics and Management Science 2: 3-21.

Streeck, W., and L. Kenworthy. 2005. Theories and practices of neocorporatism. In The handbook of political sociology: states, civil societies, and globalization, ed. W. Streeck, L. Kenworthy, T. Janoski, R.R. Alford, A.M. Hicks, and M.A. Schwartz. Cambridge: Cambridge University Press.

Tullock, G. 1967. The welfare costs of tariffs, monopolises, and theft. Economic Inquiry 5: 224-232.

Van Den Broek, O. 2021. Soft Law Engagements and Hard Law Preferences: Comparing EU Lobbying Positions between UN Global Compact Signatory Firms and Other Interest Group Types. Business and Politics 23: 383-405.

Vogel, D. 2007. The market for virtue: The potential and limits of corporate social responsibility, Brookings Institution Press.

Werner, T. 2015. Gaining Access by Doing Good: The Effect of Sociopolitical Reputation on Firm Participation in Public Policy Making. Management Science 61: 1989-2011.

Williams, O.F. 2014. Corporate Social Responsibility: The Role of Business in Sustainable Development. Abingdon: Routledge.

Woll, C. 2012. The brash and the soft-spoken: Lobbying styles in a transatlantic comparison. Interest Groups and Advocacy 1: 193-214.

Publisher's Note Springer Nature remains neutral with regard to jurisdictional claims in published maps and institutional affiliations. 